\title{
H-Y ANTIGEN STUDIES IN THIRTY PATIENTS WITH ABNORMAL GONADAL DIFFERENTIATION: CORRELATIONS AMONG SEX CHROMOSOME COMPLEMENT, H-Y ANTIGEN, AND GONADAL TYPE
}

\author{
Kiyomi YAMADA ${ }^{1}$ and Koichiro IsURUGI ${ }^{2}$ \\ ${ }^{1}$ Division of Genetics, Clinical Research Institute, and \\ ${ }^{2}$ Department of Urology, National Medical Center Hospital, \\ 1-Toyamacho, Shinjuku-ku, Tokyo 162, Japan
}

\begin{abstract}
Summary The expression of $\mathrm{H}-\mathrm{Y}$ antigen was examined in 30 patients with abnormal gonadal differentiation. Four patients with $\mathrm{XX}$ true hermaphroditism and 8 with $\mathrm{XX}$ male syndrome were all $\mathrm{H}-\mathrm{Y}$ positive, in spite of the absence of cells bearing $Y$ chromosome in the body. Of the 7 patients studied with XY gonadal dysgenesis, 6 patients were $\mathrm{H}-\mathrm{Y}$ positive and one was negative. The reduced antigen titer as compared to normal males was observed in one of the $\mathrm{H}-\mathrm{Y}$ positive patients. Clinical and cytogenetic studies in the total 30 patients adding 4 of mixed gonadal dysgenesis and 3 of male pseudohermaphroditism, could not establish strict correlations among sex chromosome complement, $\mathrm{H}-\mathrm{Y}$ antigen, and gonadal type of patients. However, a distinct association was recognized; when testicular structure was seen in the gonad, the H-Y antigen of the patient was always positive regardless of sex chromosome complement. In this study, our modified method and technical problems on the H-Y antigen examination are described, and genetic mechanisms for the regulation of $\mathrm{H}-\mathrm{Y}$ antigen expression are discussed.
\end{abstract}

\section{INTRODUCTION}

Various kinds of abnormal sex chromosome complement had been revealed in man, and consequently, an important role of the $\mathrm{Y}$ chromosome in differentiation of the embryonal gonad was well acknowledged. Namely, it was generally admitted that the $\mathrm{Y}$ chromosome is a strong testis determinant and in its absence an ovary is formed. However, $\mathrm{XX}$ males and $\mathrm{XX}$ true hermaphrodites among human sex anomalies were found to be the only exception to this assumption, both having an $\mathrm{XX}$ sex complement and testicular structure in the gonad. To explain these disease conditions, mosaicism or $\mathrm{Y}-\mathrm{X}$ translocation had been considered as most likely (Fergusson-Smith, 1966).

Received June 13, 1981 
A male-specific antigen was discovered by Eichwald and Silmser (1955) in the mouse, which was later called as histocompatibility-Y (H-Y) antigen. The first application of $\mathrm{H}-\mathrm{Y}$ antigen examination to humans was reported by Wachtel et al. (1976) and revealed that XX males and XX true hermaphrodites were $\mathrm{H}-\mathrm{Y}$ antigen positive. The H-Y antigen is a cell surface component and is thought to be controlled by a Y-chromosomal gene. In parallel with accumulation of experimental evidence supporting that $\mathrm{H}-\mathrm{Y}$ antigen may be the testis-determinating factor in mammals, rapid expansion of knowledge on $\mathrm{H}-\mathrm{Y}$ antigen phenotype in various human sex-anomaly patients was made and the underlying genetic mechanisms now come to the time to be discussed actively (see the review of Wachtel and Ohno, 1979).

Methodological problems on the examination of $\mathrm{H}-\mathrm{Y}$ antigen, however, are still existent for many reasons. In the present study, we wish to describe our modified method for the H-Y antigen detection in detail and the results of $\mathrm{H}-\mathrm{Y}$ antigen studies in 30 seX-anomaly patients including $\mathrm{XX}$ males and XX true hermaphrodites. Technical problems, clinical and cytogenetic correlations, and genetic mechanisms of the $\mathrm{H}-\mathrm{Y}$ antigen expression are discussed.

\section{MATERIALS AND METHODS}

The chromosome examination was done in cells obtained by the conventional blood-culture method. Peripheral leukocytes were also used for $\mathrm{H}-\mathrm{Y}$ antigen typing. The examination of $\mathrm{H}-\mathrm{Y}$ antigen was performed according to the sperm cytotoxicity test of Goldberg et al. (1971) with following modifications by us.

1) Production of $H-Y$ antiserum in mice. An inbred strain of C57BL/6 mice was used. Each of female virgin mice aged 7-9 weeks was injected weekly with $1 \mathrm{ml}$ of $0.85 \%$ saline containing $3-5 \times 10^{7}$ male spleen cells intraperitoneally. After 6 serial injections, blood was taken 7 days after the last injection. The serum was heat-inactivated, and stored at $-70^{\circ} \mathrm{C}$ until just before use.

2) Preparation of antiserum for use. Eight $\mathrm{ml}$ of heparinized blood of the patient being tested or normal control persons was mixed with $2 \mathrm{ml}$ of $5 \%$ dextran in saline, and allowed to stand for $30 \mathrm{~min}$ in a test tube. The upper part of the blood containing leukocytes richly was centrifuged at $1,000 \mathrm{rpm}$ for $10 \mathrm{~min}$. The cells were rinsed twice with $0.02 \%$ EDTA-Hanks' solution. Absorption of the $\mathrm{H}-\mathrm{Y}$ antibody was accomplished by suspending over $10^{7}$ leukocytes in $100 \mu \mathrm{l}$ of antiserum diluted $1 / 4$ with saline in a small test tube and by allowing the suspension on ice for $50 \mathrm{~min}$. After centrifuged at $500 \mathrm{~g}$ for $10 \mathrm{~min}$, the supernatant serum was used in cytotoxicity tests.

3) Preparation for sperm suspension. The epididymes were removed from an adult $\mathrm{BALB} / \mathrm{c}$ mouse, sliced into several pieces, and suspended in $0.5 \mathrm{ml}$ of RPMI 1640 medium containing $5 \%$ of heat-inactivated fetal calf serum. The upper part of the suspension containing free sperm was taken, diluted to a concentration of 
$5 \times 10^{6} / \mathrm{ml}$, and immediately used in cytotoxicity tests.

4) Preparation of rabbit serum. Selected rabbit serum was used as complement source. One $\mathrm{ml}$ of serum diluted $1 / 4$ with saline containing $0.01 \mathrm{M}$ EDTA was mixed with liver and spleen cells of a female BALB/c mouse in an approximate proportion of four volume serum to one volume packed cells. The cell suspension in a small tube was placed on ice for $50 \mathrm{~min}$ to absorb the rabbit anti-mouse antibody occurring naturally. After centrifuged at $500 \mathrm{~g}$ for $10 \mathrm{~min}$, the absorbed serum was further diluted $1 / 2$ or $1 / 3$ with saline containing $0.02 \mathrm{M} \mathrm{Ca}$ - and $\mathrm{Mg}$-ions.

5) Sperm cytotoxicity test. Antiserum aliquots after absorption with leukocytes of the patient being tested or of normal human males and females as controls, were tested for their residual cytotoxicity against mouse sperm. Each volume $(20 \mu 1)$ of i) antiserum (serially diluted $1 / 4$ to $1 / 32$ ), ii) sperm suspension, and iii) rabbit serum, were mixed in a small test tube and incubated at $37^{\circ} \mathrm{C}$ for $50 \mathrm{~min}$. Besides duplicated sets of antiserum absorbed with patient's cells, the following four series with antiserum treated differently were set up as controls; absorbed with human normal male or female leukocytes, unabsorbed, and no antiserum. Sperm counts were made $10 \mathrm{~min}$ after addition of $20 \mu 1$ of a freshly prepared solution of $0.2 \%$ trypan-blue in saline. Sperm stained with the dye were scored as dead under observation with a Normarski interference phase contrast microscope (Olympus Inc.). Usually, 100 sperm per test tube were quickly counted.

\section{RESULTS AND DISCUSSION}

\section{1. $H$ - $Y$ antigen studies in normal controls}

In Fig. 1, normal ranges of human male and female curves in cytotoxicity tests are graphically shown. From the results of normal controls, it was clear that at $1 / 4$ and $1 / 8$ dilutions of antiserum the residual cytotoxic activities after absorption with $\mathrm{XY}$ cells were significantly lower than those after absorption with $\mathrm{XX}$ cells.

\section{2. $H$-Y antigen studies in 30 sex-anomaly patients}

Results of H-Y antigen typing and chromosome analysis, together with information on the gonads of patients studied, are summarized in Table 1. Data in cytotoxicity tests of patients with $\mathrm{XX}$ true hermaphroditism, XX male syndrome, and $X Y$ gonadal dysgenesis are graphically shown in Fig. 2, respectively.

$X X$ true hermaphroditism and $X X$ male syndrome. We studied 4 cases of $\mathrm{XX}$ true hermaphroditism and 8 of XX male syndrome. All of them (Cases 1-12) were $\mathrm{H}-\mathrm{Y}$ antigen positive. Indeed, there was no exception among over 20 previously reported cases of these diseases (Wachtel et al., 1976a; Fraccaro et al., 1979). Y-X translocation or mosaicism with cells bearing $Y$ chromosome was not observed in the present cases, though the abnormal $\mathrm{X}(\mathrm{Xp}+)$ chromosome suggesting $\mathrm{Y}-\mathrm{X}$ translocation was reported only in a few cases (Evans et al., 1979). Therefore, it is natural to consider that gene(s) responsible for the expression of $\mathrm{H}-\mathrm{Y}$ antigen 


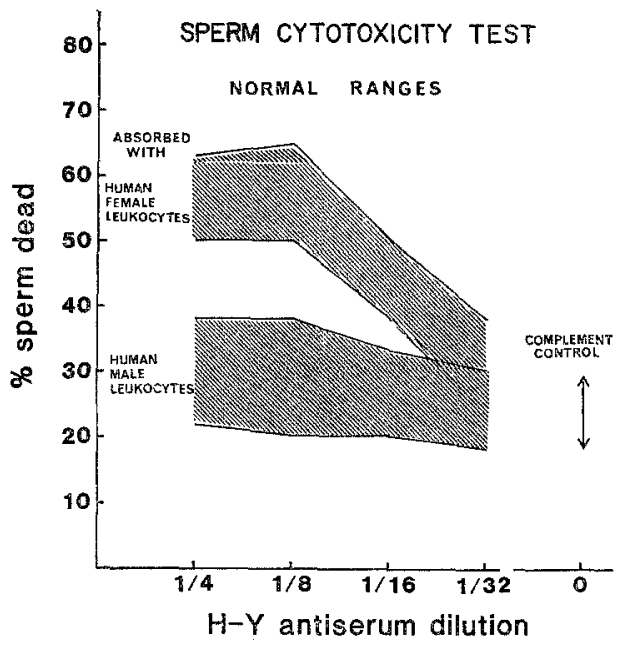

Fig. 1. The proportion of dead sperm according to serial dilutions of antiserum; a normal range for females (obtained from the total 20 tests from 6 individuals), and a normal range for males (obtained from the total 20 tests from 8 individuals).

should exist within a $46, \mathrm{XX}$ genome of these patients. The presence of reported cases in which $\mathrm{XX}$ true hermaphroditism and $\mathrm{XX}$ male syndrome were both found in the same family, has suggested a common genetic basis for the two disease conditions and an autosomal mode of inheritance in the families reported (Berger et al., 1970; Kasdan et al., 1973).

$X Y$ gonadal dysgenesis. We studied 7 cases of $X Y$ gonadal dysgenesis (Cases 13-19). Of the 7 cases studied, 6 cases were H-Y positive and one (Case 17) was negative. The reduced antigen titer was observed in one (Case 13) of the positive cases. Our present results were similar to the results of previously reported cases; of the 24 cases reported, 16 positive, 6 negative, and 2 were positive with the reduced antigen titer (Ghosh et al., 1978; Wolf, 1979; Wachtel et al., 1980a).

Analysis of correlations among sex chromosome complement, $H-Y$ antigen, and gonadal type. Data summarized in Table 1, led us to the conclusion that there was no correlation in the strict sense among karyotype, H-Y antigen, and gonadal type of the 30 patients studied here. However, it was noted that when testicular development was seen in the gonad, the $\mathrm{H}-\mathrm{Y}$ antigen was always positive regardless of sex chromosome complement. In other words, none of patients was observed, having a testis without the expression of $\mathrm{H}-\mathrm{Y}$ antigen on peripheral leukocytes. This distinct association is also valid in the light of evidence obtained in reported cases.

\section{Genetic mechanisms for the regulation of $H-Y$ antigen expression}

Since the gene for human H-Y antigen is throught to be located on the short 

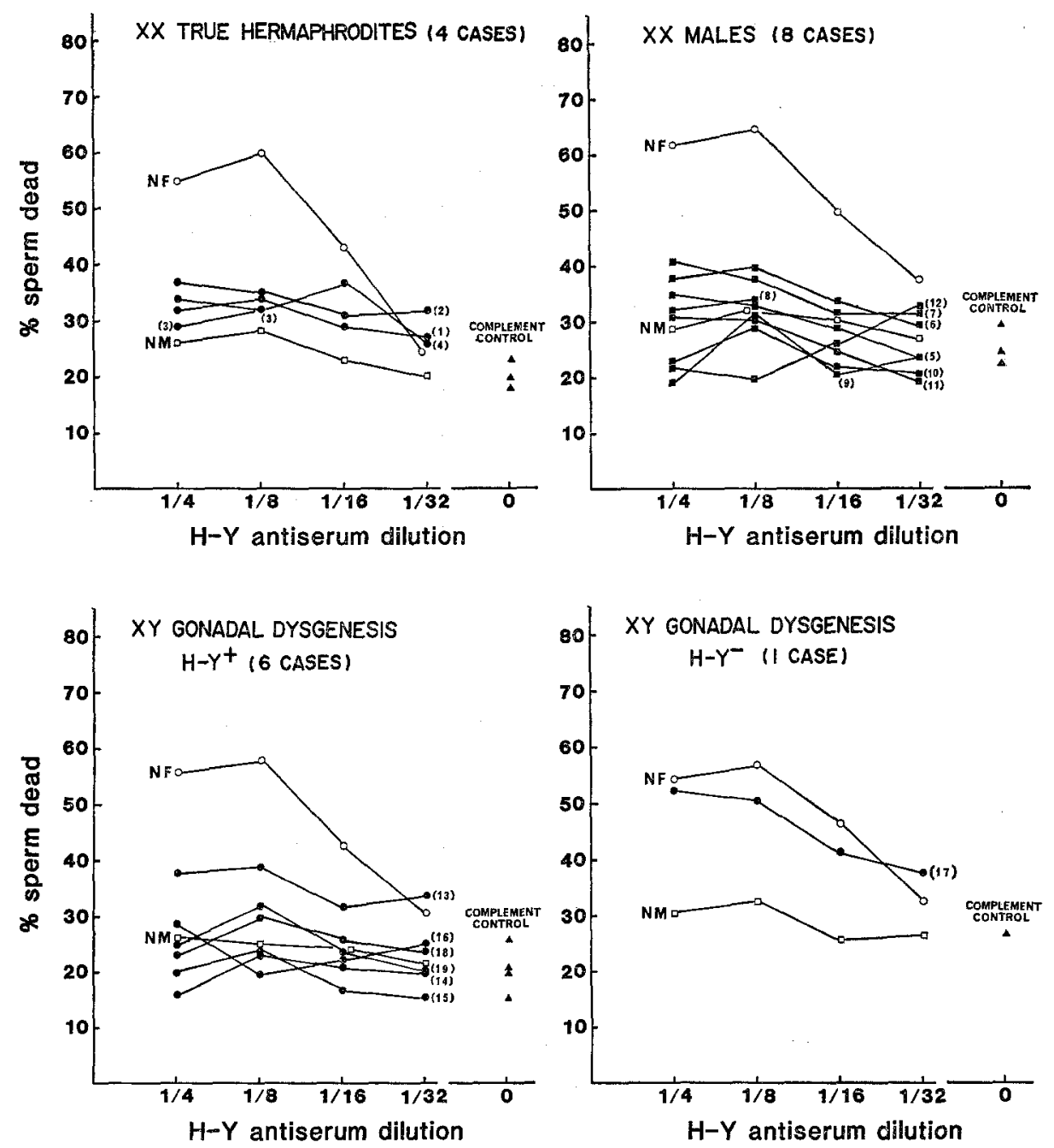

Fig. 2. Determination of $\mathrm{H}-\mathrm{Y}$ phenotype by residual cytotoxic activities of antiserum absorbed with patient's leukocytes. Numbers in parentheses are Case Nos., and curves of normal female (NF) and normal male(NM) are expressed as a mean of total controls.

arm of the $Y$ chromosome (Koo et al., 1977), present results of Cases 21-23 and 26 supporting this, coincidence between the presence of $Y$ chromosome and the presence of $\mathrm{H}-\mathrm{Y}$ antigen or testis in the gonad is well explained. When this coincidence is disturbed by mutation, various forms of intersexuality come out. Accordingly, information on genetic mechanisms in the H-Y antigen system is obtained from studies in patients with abnormal gonadal differentiation.

Observations to date in intersexuality of mammals including man, which can not be explained by such an idea as only the $\mathrm{Y}$ chromosome having the gene for the 
Table 1. Results of analyses on $\mathrm{H}-\mathrm{X}$ antigen, karyotype, and gonadal type in 30 patients studied here

\begin{tabular}{|c|c|c|c|c|c|c|}
\hline $\begin{array}{l}\text { Case } \\
\text { No. }\end{array}$ & Age & $\begin{array}{l}\text { Phenotypic } \\
\text { Sex }\end{array}$ & Clinical Diagnosis & $\begin{array}{c}\mathrm{H}-\mathrm{Y} \\
\text { Antigen }\end{array}$ & Karyotype & $\begin{array}{l}\text { Type of the } \\
\text { Gonads }\end{array}$ \\
\hline 1 & $10 \mathrm{y}$ & Male & True hermaphroditism & $\mathrm{H}-\mathrm{Y}^{+}$ & $46, x x$ & $\left\{\begin{array}{l}\text { Rt: Ovotestis } \\
\text { Lt: Ovotestis }\end{array}\right.$ \\
\hline 2 & $21 y$ & Male & True hermaphroditism & $\mathrm{H}-\mathrm{Y}^{+}$ & $46, \mathrm{xx}$ & $\left\{\begin{array}{l}\text { Rt:Ovotestis } \\
\mathrm{Lt}: \text { Ovotestis }\end{array}\right.$ \\
\hline 3 & $1 y$ & Male & True hermaphroditism & $\mathrm{H}-\mathrm{Y}^{+}$ & $46, x x$ & $\left\{\begin{array}{l}\text { Rt: } ? \\
\mathrm{Lt}: ?\end{array}\right.$ \\
\hline 4 & $2 \mathrm{y}$ & Male & True hermaphroditism & $H-x^{+}$ & $46, x x$ & $\left\{\begin{array}{l}\text { Rt: Ovotestis } \\
\text { It:Ovotestis }\end{array}\right.$ \\
\hline$\xi^{5}$ & $7 y$ & Male & $\mathrm{xx}$ male syndrome & $\mathrm{H}-\mathrm{Y}^{+}$ & $46, x x$ & $\left\{\begin{array}{l}\text { Rt: Testis } \\
\text { Lt:Testis }\end{array}\right.$ \\
\hline 6 & $4 y$ & Male & $x x$ male syndrome & $\mathrm{H}-\mathrm{Y}^{+}$ & $46, \mathrm{xx}$ & $\left\{\begin{array}{l}\text { Rt: Testis } \\
\text { It:Testis }\end{array}\right.$ \\
\hline 7 & $9 \mathrm{y}$ & Male & $\mathrm{xx}$ male synarome & $\mathrm{H}-\mathrm{Y}^{+}$ & $46, x x$ & $\left\{\begin{array}{l}\text { Rt: Testis } \\
\text { It:Testis }\end{array}\right.$ \\
\hline 8 & $40 y$ & Male & Xx male syndrome & $\mathrm{H}-\mathrm{Y}^{+}$ & $46, x x$ & $\left\{\begin{array}{l}\text { Rt:Testis } \\
\text { Lt:Testis }\end{array}\right.$ \\
\hline 9 & $29 y$ & Male & $\mathrm{xx}$ male syndrome & $\mathrm{H}-\mathrm{Y}^{+}$ & $46, x x$ & $\left\{\begin{array}{l}\text { Rt:Testis } \\
\text { Lt:Testis }\end{array}\right.$ \\
\hline 10 & $28 y$ & Male & $\mathrm{xx}$ male syndrome & $\mathrm{H}-\mathrm{Y}^{+}$ & $46, x x$ & $\begin{array}{l}\text { Rt:Testis } \\
\text { Lt:Testis }\end{array}$ \\
\hline 11 & $17 y$ & Male & $\mathrm{xx}$ male synarome & $I X-X^{+}$ & $46, x x$ & $\left\{\begin{array}{l}\text { Rt:Testis } \\
\text { It:Testis }\end{array}\right.$ \\
\hline 12 & $6 m$ & Male & $\mathrm{xx}$ male syndrome & $\mathrm{H}-\mathrm{Y}^{+}$ & $46, x X_{6}$ & $\left\{\begin{array}{l}\text { Rt:Testis } \\
\text { Lt:Testis }\end{array}\right.$ \\
\hline 13 & $3 y$ & Female & $X Y$ gonadal dysgenesis & $H-Y^{ \pm}$ & $46, X Y$ & $\begin{array}{l}\text { Rt:Gonadoblastoma } \\
\text { Lt: Dysgerminoma }\end{array}$ \\
\hline$\left\{^{14}\right.$ & $28 y$ & Female & $X Y$ gonadaI dysgenesis & $\mathrm{H}-\mathrm{Y}^{+}$ & $46, X Y$ & $\left\{\begin{array}{l}\text { Rt: Streak } \\
\text { Lt:Streak }\end{array}\right.$ \\
\hline 15 & $26 \mathrm{y}$ & Female & $X Y$ gonadal dysgenesis & $\mathrm{H}-\mathrm{Y}^{+}$ & $46, X Y$ & \{ Rt: Streak \\
\hline 16 & $8 \mathrm{y}$ & Female & $X Y$ gonadal dysgenesis & $\mathrm{H}-\mathrm{Y}^{+}$ & $46, X Y$ & $\begin{array}{l}\text { \{t: Gonadoblastoma } \\
\text { Lt: Gonadoblastoma } \\
\text { Rt:? }\end{array}$ \\
\hline 17 & $3 y$ & Female & $\mathrm{XY}$ gonadal dysgenesis & $\mathrm{H}-\mathrm{Y}^{-}$ & $46,8 Y$ & $\begin{array}{l}\text { Lt:? } \\
\text { It:? } \\
\text { Rt: Streak }\end{array}$ \\
\hline$\left\{^{18}\right.$ & $17 y$ & Female & $X Y$ gonadal dysgenesis & $\mathrm{E}-\mathrm{Y}^{+}$ & $46, X Y$ & $\left\{\begin{array}{l}\text { Rt: Streak } \\
\text { Lt: Streak } \\
\text { Rt: Streak }\end{array}\right.$ \\
\hline 19 & $17 y$ & Female & XY gonadal dysgenesis & $\mathrm{E}-\mathrm{Y}^{\top}$ & $46, X Y$ & \{t: Streak \\
\hline 20 & $3 y$ & Fenale & Mixed gonadal dysgenesis & $\mathrm{H}-\mathrm{Y}^{+}$ & $46, \mathrm{XY}$ & $\begin{array}{l}\text { Rt:Testis } \\
\text { Lt:Streak } \\
\text { Rt: Streak }\end{array}$ \\
\hline 21 & $45 y$ & Female & Mixed gonadal dysgenesis & $\mathrm{H}-\mathrm{Y}^{+}$ & $45, X / 46, x Y q-$ & $\begin{array}{l}\text { ft: Streak } \\
\text { Lt:Testis } \\
\text { Rt:Absence }\end{array}$ \\
\hline 22 & $1 y$ & Ambiguous & Mixed gonadal dysgenesis ? & $\mathrm{H}-\mathrm{Y}^{+}$ & $\begin{array}{l}45, \mathrm{X} / 46, \mathrm{X} \\
\operatorname{idic}(\mathrm{Yq})\end{array}$ & $\begin{array}{l}\left\{\begin{array}{l}\text { Rt:Absence } \\
\text { Lt:Testis } \\
\text { Rt:Testis }\end{array}\right. \\
\text { Rt: }\end{array}$ \\
\hline 23 & $2 \mathrm{~m}$ & Ambiguous & Mixed gonadaI dysgenesis ? & $\mathrm{H}-\mathrm{Y}^{+}$ & $45, \mathrm{x} / 46, \mathrm{xyq}-$ & $\begin{array}{c}\text { Ltt:Aggregates of } \\
\text { germ cells ? }\end{array}$ \\
\hline 24 & $40 y$ & Female & Male pseudohermaphroditism & $\mathrm{H}-\mathrm{Y}^{+}$ & $46, X Y$ & $\left\{\begin{array}{l}\text { Rt: Testis } \\
\text { Lt: Testis (seminoma } \\
\text { Rt: Testis }\end{array}\right.$ \\
\hline 25 & $2 y$ & Ambiguous & Male pseudohermaphroditism & $\mathrm{H}-\mathrm{Y}^{+}$ & $46, X Y$ & $\begin{array}{l}\text { Rt: Testis } \\
\text { Lt:Testis } \\
\text { Rt:Testis ? }\end{array}$ \\
\hline 26 & $23 y$ & Female & Male pseudohermaphroditism & $? \mathrm{H}-\mathrm{Y}^{+}$ & $\begin{array}{l}45, \mathrm{X} / 46, \mathrm{X} \\
\tan \operatorname{dup}(\mathrm{Yq})\end{array}$ & 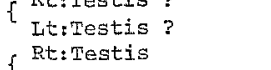 \\
\hline 27 & $22 y$ & Male & Hypogonadism & $\begin{array}{l}\mathrm{H}-\mathrm{Y} \\
+\end{array}$ & $46, \mathrm{XYq}-$ & $\begin{array}{l}\text { Lt:Testis } \\
\text { Rt:Testis }\end{array}$ \\
\hline 28 & $35 y$ & Male & Hypogonadism & $H-Y^{+}$ & $46, \mathrm{XYq-}$ & It:Testis \\
\hline 29 & $10 \mathrm{y}$ & Ambiguous & Klinefelter syndrome & $\mathrm{H}-\mathrm{Y}^{+}$ & $49, \mathrm{XXXXY}$ & $\left\{\begin{array}{l}\text { Rt:Testi,s } \\
\text { Lt: Testis }\end{array}\right.$ \\
\hline 30 & $65 y$ & Male & Leukemia & $\mathrm{H}-\mathrm{Y}^{+}$ & $46, \operatorname{Xinv}\left(Y_{q}\right) *$ & $\left\{\begin{array}{l}\text { Rt:Testis } \\
\text { It:Testis }\end{array}\right.$ \\
\hline
\end{tabular}

Cases 5-6, and 14-15, are sibs. Cases 18-19 are monozygotic twins. *The chromosome anomaly was constitutional.

Jpn. J. Human Genet. 
regulation of the $\mathrm{H}-\mathrm{Y}$ expression, may be summarized briefly as follows: i) Human $\mathrm{XX}$ true hermaphrodites and XX males are invariably $\mathrm{H}-\mathrm{Y}$ positive. The analogy to this, is seen in dogs (Selden et al., 1978), mice (Bennett et al., 1977), and goats (Wachtel et al., 1978). ii) Though the majority of human patients with XY gonadal dysgenesis are $\mathrm{H}-\mathrm{Y}$ positive, the minority are $\mathrm{H}-\mathrm{Y}$ negative. Fertile $\mathrm{XY}$ females, being H-Y negative, are reported in the wood lemming (Wachtel et al., 1976b). iii) Human patients with Turner syndrome having $45, \mathrm{X}$ or $46, \mathrm{Xi}(\mathrm{Xq})$ or $46, \mathrm{XXp}-$ karyotype are invariably $\mathrm{H}-\mathrm{Y}$ positive, the antigen titer being reduced as compared to normal males (Wolf et al., 1980; Wachtel et al., 1980b). The same condition to. this, is reported in 39, X mice (Engle et al., 1981). iv) Inducible effects of H-Y antigen to testicular differentiation depend on a threshold.

The most acceptable postulate, at present, which is able to explain all of the above findings without discrepancy, is a genetic hypothesis which has been proposed by Wolf (Wolf, 1980; Wolf et al., 1980): The expression of an autosomally localized structural gene for $\mathrm{H}-\mathrm{Y}$ antigen is regulated by an X-linked repressor gene and by a Y-linked inducer gene. According to the Wolf's hypothesis, XX true hermaphroditism and $X X$ male syndrome may be due to mutation of the $X$-linked repressor gene, and $\mathrm{H}-\mathrm{Y}$ negative cases of $\mathrm{XY}$ gonadal dysgenesis may be caused by mutation of the $Y$-linked inducer gene. $H-Y$ positive cases of $X Y$ gonadal dysgenesis can be explained as a $\mathrm{H}-\mathrm{Y}$ antigen receptor defect. Under this hypothesis, in normal $\mathrm{XX}$ females the repressor gene should not undergo inactivation and its gene locus is tentatively assigned to $\mathrm{Xp} 223$ from analysis of an $\mathrm{X} / \mathrm{Y}$ translocation case (Wolf et al., 1980). The evidence that genes on the Xp223 escape $\mathrm{X}$-inactivation, has been obtained by other studies (Tiepolo et al., 1980). As for the locus of the H-Y structural gene, of particular interest are the recent reports that three $\mathrm{XY}$ females with campomelic dysplasia, a disease inherited as an autosomal recessive trait, were found to be H-Y negative (Bricarelli et al., 1981; Puck et al., 1981).

\section{Technical problems on the $H-Y$ antigen examination}

Though several methods for the $\mathrm{H}-\mathrm{Y}$ antigen detection already have been reported, common technical problems seem to exist in any method; complicated technical procedures and low reproducibility of the results obtained. These are mostly due to the reason that $\mathrm{H}-\mathrm{Y}$ antiserum is low titered and contaminated with autoantibodies. In the present study, it was fairly easy to determine the H-Y phenotype as positive or negative, but comparison of antigen titers between different patients was impossible due to fluctuation of control baselines. Since the quantitative difference of $\mathrm{H}-\mathrm{Y}$ antigen titers has recently become an important problem, the reliable method of quantitative assays is now needed. So that, the recent report of high titers of monoclonal antibody obtained by hybridoma technique (Koo et al., 1981), has brought us an expectation to develop more easy, reliable methods such as radioimmunoassays or direct immunofluorescence method in the very near future. 
Acknowledgments We express our hearty thanks to the following clinicians for sending us blood samples and clinical data of patients: Dr. Tadashi Kajii, Dept. of Pediatrics, Yamaguchi University; Dr. Ken Hayashi, Dept. of Gynecology, Kyoto University; Dr. Hiroko Fujita, Dept. of Child Health, Osaka Ciîy University; Dr. Shin-ichiro Nanko, Brain Res. Inst., Drs. Makoto Higurashi, and Yoshiaki Tsuchida, Dept. of Pediatrics, University of Tokyo; Dr. Haruo Itoh, Dept. of Urology, Chiba University; Dr. Norio Niikawa, Dept. of Pediatrics, Hokkaido University. And, we very appreciate Prof. Dr. Tadao Niijima, Dept. of Urology, University of Tokyo, for his helpful advice and supports in many respects.

\section{REFERENCES}

Bennett, D., Mathieson, B.J., Scheid, M., Yanagisawa, K., Boyse, E.A., Wachtel, S.S., and Cattanach, B.M. 1977. Serological evidence for H-Y antigen in Sxr,XX sex-reversed phenotypic males. Nature 265: 255-257.

Berger, R., Abonyi, D., Nodot, A., Vialatte, J., and Lejeune, J. 1970. Hermaphrodisme vrai et "garcon XX" dans une fratrie. Rev. Eur. Etud. Clin. Biol. 15: 330-333.

Bricarelli, F.D., Fraccaro, M., Kindsten, J., Müler, U., Baggio, P., Carbone, L.D.L., Hjerpe, A., Lindgren, F., Mayerova, A., Ringertz, H., Ritzen, E.M., Rovetta, D.C., Sicchero, C., and Wolf, U. 1981. Sex-reversed XY females with campomelis dysplasia are H-Y negative. Hum. Genet. 57: $15-22$.

Eichwald, E.J., and Silmser, C.R. 1955. Communication. Transpla. Bull. 2: 148-149.

Engel, W., Klemme, B., and Ebrecht, A. 1981. Serological evidence for H-Y antigen in XO-female mice. Hum. Genet. 57: 68-70.

Evans, H.J., Buckton, K.E., Spowart, G., and Carothers, A.D. 1979. Heteromorphic X chromosomes in 46, XX males: Evidence for the involvement of X-Y interchange. Hum. Genet. 49: 11-31.

Fergusson-Smith, M.A. 1966. X-Y chromosome interchange in the etiology of true hermaphroditism and of XX Klinefelter's syndrome. Lancet $\mathrm{II}: 475-476$.

Fraccaro, M., Tiepolo, L., Zuffardi, O., Chiumello, G., di Natale, B., Gargantini, L., and Wolf, U. 1979. Familial XX true hermaphroditism and the H-Y antigen. Hum. Genet. 48: 45-52.

Ghosh, S.N., Shah, P.N., and Gharpure, H.M. 1978. Absence of H-Y antigen in XY females with dysgenetic gonads. Nature 276: 180-181.

Goldberg, E.H., Boyse, E.A., Bennett, D., Scheid, M., and Carswell, E.A. 1971. Serological demonstration of H-Y (male) antigen on mouse sperm. Nature 232: 478-480.

Kasdan, R., Nankin, H.R., Troen, P., Wald, N., Pan, S., and Yanaihara, T. 1973. Paternal transmission of maleness in XX human beings. New Engl. J. Med. 288: 539-545.

Koo, G.C., Wachtel, S.S., Krupen-Brown K., Mittle, L.R., Breg, W.R., Genel, M., Rosenthal, L.M., Borgaonkar, D.S., Miller, D.A., Tantravahi, R., Shreck, R.R., Erlanger, B.J., and Miller, O.J. 1977. Mapping the locus of the H-Y gene on the human Y chromosome. Science 198: $940-942$.

Koo, G.C., Tada, N., Chaganti, R., and Hammerling, U. 1981. Application of monoclonal antiHY antibody for human H-Y typing. Hum. Genet. 57: 64-67.

Puck, S.M., Haseltine, F.P., and Francke, U. 1981. Absence of H-Y antigen in an XY female with campomelic dysplasia. Hum. Genet. 57: 23-27.

Selden, J.R., Wachtel, S.S., Koo, G.C., Haskins, M.E., and Patterson, D.F. 1978. Genetic basis of XX male syndrome and XX true hermaphroditism: evidence in the dog. Science 201: 644646.

Tiepolo, L., Zuffardi, O., Fraccaro, M., di Natale, D., Gargantini, L., Müler, C.R., and Ropers, H.H. 1980. Assignment by deletion mapping of the steroid sulfatase X-linked ichthyosis locus to Xp223. Hum. Genet. 54: 205-206. 
Wachtel, S.S., Koo, G.C., Breg, W.R., Thaler, T.H., Dillard, G.M., Rosenthal, I.M., Dosik, H., Gerald, P.S., Saenger, P., New, M., Lieber, E., and Miller, O.J. 1976a. Serological detection of a Y-linked gene in XX males and XX true hermaphrodites. New Engl. J. Med. 295: 750-754.

Wachtel, S.S., Koo, G.C., Ohno, S., Gropp, A., Dev, V.G., Tantravahi, R., Miller, D.A., and Miller, O.J. 1976b. H-Y antigen and the origin of XY female wood lemmings (Myopus schisticolor). Nature 264: 638-639.

Wachtel, S.S., Basrur, P., and Koo, G.C. 1978. Recessive male-determinating genes. Cell 15: 279-281.

Wachtel, S.S., and Ohno, S. 1979. The immunogenetics of sexual development. Proc. Med. Genet. 3: 109-142.

Wachtel, S.S., Koo, G.C., de la Chapelle, A., Kallio, H., Heyman, J.M., and Miller, O.J. $1980 a$. $\mathrm{H}-\mathrm{Y}$ antigen in 46,XY gonadal dysgenesis. Hum. Genet. 54: 25-30.

Wachtel, S.S., Koo, G.C., Roy Breg, W., and Genel, M. 1980b. H-Y antigen in X,i(Xq) gonadal dysgenesis: Evidence of X-linked genes in testicular differentiation. Hum. Genet. 56: 183-187.

Wolf, U. 1979. XY gonadal dysgenesis and H-Y antigen. Report on 12 cases. Hum. Genet. 47: 269-277.

Wolf, U. 1980. Turner syndrome patients are H-Y positive. Hum. Genet. 54: 315-318.

Wolf, U., Fraccaro, M., Mayerova, A., Hecht, T., Maraschio, P., and Hameister, H. 1980. A gene controlling $\mathrm{H}-\mathrm{Y}$ antigen on the $\mathrm{X}$ chromosome. Tentative assignment by deletion mapping to Xp223. Hum. Genet. 54: 149-154. 